\title{
Text rhythmic system: Its energetic and subliminal potentials
}

\author{
Alla Kalyta \\ National Technical University of Ukraine "Kyiv Polytechnic Institute", Ukraine
}

\begin{abstract}
The article introduces scientific considerations concerning the energetic nature and origin of rhythm subliminal potential in a spoken text as well as the mechanisms of its impact on the recipient. The paper advances the idea that rhythm energetics and its subliminal potential is based on such postulates: (1) rhythm is generated in the speaker's psyche at the levels of his/her unconscious (or existential being) and subconscious (or mental and transcendental beings) spheres; (2) the text rhythmic system has a definite emotional and pragmatic potentials that realize a latent manipulative and subliminal influence; (3) generation of the spoken text tempo-rhythm is carried out by means of integrating micro-rhythms of all levels of the speaker's inner speech into the internal macro-rhythm, which is materialized in the form of an outer tempo-rhythm as a complex means of achieving a subliminal effect of speech. The article also outlines the prospects of studying a subliminal nature of rhythm.
\end{abstract}

Keywords: rhythm, tempo-rhythm, energetic potential, mechanism of generation, subliminal influence

\section{Introduction}

Rhythm as a unique communicative phenomenon is actively described by linguists on the grounds of contemporary theoretical views and experimental data, obtained by the researchers of such areas of scientific knowledge as philosophy, study of art, psychology, musicology, physiology, computer science, mathematics, neuropsychology, psycholinguistics, psychophysiology, neurophysiology, psychoacoustics, etc. since its treatment as a purely phonetic or syntactic phenomenon is not sufficient for the solution of emerging problems connected with the functioning of rhythm in prosaic texts.

At the same time linguists have recently admitted that the issue of energetic nature of the rhythm's subliminal potential generation is one of the most actual issues of the general problem of rhythm functioning in communication. Nevertheless, the papers known in linguistic literature lack theoretical results that present a systemic hypothesizing of scientific views on the energetic nature of the origin of speech rhythm subliminal potential. 
Therefore, the objective of the undertaken methodological study is a systemic hypothesizing of scientific considerations concerning the energetic nature and origin of rhythm subliminal potential in a prosaic text as well as the substantiation of mechanisms of its impact on the recipient.

\section{Conceptual and theoretical background for studying rhythm energetics and its subliminal potential in prosaic texts}

Proceeding from the synergism of speech generating and decoding mechanisms, speech subliminal effect is interpreted in the paper as the result of the spoken text rhythmic system's functioning whose elements, along with the rhythm proper, comprise the means of all language levels traditionally studied by linguists.

Due to this, rhythm is regarded in the paper not only in its narrow meaning but also in its broad understanding when it interacts with the means of other language levels. Such a consideration is based on the idea that any individual component of the prosodic system without interaction with its other components is not sufficient to form a stable rhythmic concept in the person's auditory-and-emotional memory, being capable of performing the function of a particular rhythmic concept-prototype in his/her psychic sphere. This is important since subliminal effects can only be achieved when the sender and recipient's communicative cultures coincide, the prerequisite of which is the presence of an adequately generated and decoded rhythmic concept-prototype in their memory.

The use of these ideas as well as the theoretical principle of conserving the utterance emotional-and-pragmatic potential (Kalyta 2007) allowed us to formulate the quintessence of energetic approach to linguistic studies. It consists in the attempt to describe phonetic phenomena as a result of the stochastic speech generation, whose motive force is the psychophysiological energy with its inherent ability to be redistributed between an individual's consciousness and spheres of his/her sub- and unconsciousness, responsible for the speaker's choice of linguistic and paralinguistic means of communication.

Thus, employing a strictly scientific approach, it is rational to carry out a brief review of the rhythm properties, peculiarities of its manifestation and characteristics, highlighted in a number of works by Ukrainian and foreign researchers, who describe rhythm in its broad meaning. As regards the functional purpose of rhythm in communication, there exist some opinions, according to which rhythm is viewed as a means of (1) stimulating a man to read and write (Goux 2003: 14); (2) reviving a prose (ibid.); (3) realizing structural, text-forming and expressive-and-emotional functions of speech (Jazykoznanie 1998: 416); (4) producing an artistic impact on the recipient (Zhirmunskij 1975: 569); (5) causing a psychological and emotional effect (Bojchuk 2014: 130); (6) focusing the reader's attention on particular elements of the message (Gumovskaja 2000: 6); (7) organizing the person's own speech (Meschonnic 1990: 71); (8) forming the text structure as well as the processes of conveying and perceiving information (Gumovskaja 2000: 7); (9) creating coherence and cohesion of the text (Efremov 2012: 90); (10) achieving a designated effect in speech (Babicheva 2003: 10); (11) generating and realizing the text subliminal influence (Boltaeva 2003, Bojchuk 2014: 
130). The stated above makes it obvious that the researchers seek to objectify the subliminal function of rhythm from the point of view of the individual who generates the text or the individual who perceives it.

Thus the present research of rhythm energetics and its subliminal potential in prosaic texts is based on the following postulates:

1. rhythm is generated in the speaker's psyche at the levels of his/her unconscious (or existential being) and subconscious (or mental and transcendental beings) spheres;

2. the text rhythmic system has a definite emotional-and-pragmatic potential that realizes a latent manipulative and subliminal influence;

3. generation of the spoken text tempo-rhythm is carried out by means of integrating micro-rhythms of all levels of the speaker's inner speech into the internal macrorhythm, which, being under control of the individual's consciousness, is materialized in the form of an outer tempo-rhythm.

\section{Energetic approach application to the study of the subliminal potential of the text rhythmic system}

\subsection{The results of studying the text rhythm: its definition and functions}

Guided by the basic stipulations of the method of systemic analysis applied to the functions nominated by the aforementioned researchers, one can easily be convinced that the main function of communicative rhythm in general and text or utterance rhythm in particular lies in the actualization of their subliminal influence. Moreover, taking into account its importance, the subliminal function of rhythm should be regarded and, accordingly, interpreted at all levels of its actualization as a strategic one (Kalyta 2012: 48-49, Klimenjuk 2007: 165).

In this case it is quite logical to assume that, according to their roles, all other functions reviewed above should be given a status of tactical functions, methods, ways, techniques and means, actualizing the rhythm's subliminal influence. This approach not only makes it possible to unambiguously define the leading role of rhythm in the text subliminal potential but also enhances the topicality of studying other means of speech subliminal influence in a direct correlation with rhythm as a basic element of the spoken text.

An equally important issue for the analysis undertaken in this paper is, most likely, the specificity of rhythm manifestation. Traditionally it is appropriate to regard speech rhythm as “...a regular recurrence of similar and commensurable speech units, performing structural, text-forming, expressive and emotional functions" (Jazykoznanie 1998: 416).

It is obvious that the results of realization of these and a considerable number of the above mentioned functions of rhythm should inevitably generate a wide range of alternatives of its manifestation in the variety of existing forms of speech communication.

As is known (Mourot 1960: 11-15), rhythm manifests itself in the regularity of alternating syntactical parts of sentences, the number of stresses and syllables, the character of sounds' use (alliteration, homophones); syntactical parallelism; distribution of the parts of the whole 
text or phrase according to the increasing or decreasing order in the size of these parts; repetitions (lexical or semantic); equality or inequality of the ascending and descending intonation contours of the utterance and a few other phenomena. In compliance with this, G.R. Gachechiladze emphasizes that a prosaic rhythm reveals itself predominantly in the alternation of pauses and sense units of different length, as well as the repetition of logical stresses, successions of ascending and descending intonation contours, symmetrical sentence structure and syntagms arrangement, sometimes by the introduction of refrain, alliteration, inner rhyme and assonance (Gachechiladze 1970: 208).

Viewing rhythm as a means of artistic influence, V.M. Zhirmunskij considers it as the main attribute of the text syntactic level (Zhirmunskij 1975: 575-576). Proceeding from the semantic and informational components of the text, E.I. Bojchuk, in her turn, accentuates that rhythm manifests itself in the construction of the text plot, in its architectonics and, particularly, in the system of language expressive means, with the help of which the images of literary works are created (Bojchuk 2014: 130).

Defining rhythm as a symmetry of two or several homogeneous phenomena that have a similar duration and are similarly arranged in time, E.-L. Martin reveals its manifestation in the multitude of different symmetries (Martin 1924: 170) and states that the symmetry of rhythmical stresses is the best known one (ibid. 176-177).

Within the lexical rhythm S.V. Boltaeva points out two forms of its manifestation: explicit and implicit ones. The explicit means of rhythm actualization include anaphora and a complete lexical repetition. The implicit forms consist in manifestation of rhythm by means of a repeated representation of the already mentioned notion with the help of synonyms of its primary nomination, singling out the properties and features inherent to it as well as using word-forming derivatives and the lexical units, which are semantically close to this notion at the level of associations (Boltaeva 2003: 14). In her work, as regards the latent rhythmical schemes of speech unit's semantics actualization, which facilitate a continuous intensification of the subliminal effect of a particular idea, the author underlines that the conclusive fragment, summarizing the concepts of the text in the original rhythm of their phonetic markers, is notable for its particular complexity (Boltaeva 2003: 20).

The facts stated above do not leave space for doubts that rhythm as a unique phenomenon of speech reveals itself almost at all levels of the language. Here with the equal objectivity belong the following levels: sound, intonation, lexical-and-semantic, syntactic (Jazykoznanie 1998: 416, Gumovskaja 2000: 105), phonetic, lexical, grammatical and structural-and-compositional (Bojchuk 2014: 130), prosodic-and-syntactic, semantic, compositional, plot-and-imagery (Bogatova 2009: 19), plot, imagery, space and time, thematic (Arustamova 1998: 6), etc.

It's quite obvious that a diversity of terms describing the mentioned levels explicitly reflects the authors' approaches or aspects of their treatment of speech rhythm. It is fairly convenient for the metaphorical description of the peculiarities of speech rhythm manifestation. Yet, the experimental linguistics practice requires a more strict regulation of the levels of examining rhythm actualization, and it appears quite reasonable to confine them to their classical hierarchy: phonetic, morphological, lexical-and-semantic, and syntactic ones 
(Kochergan 1999: 69). Therefore, further on we shall adhere to the classical hierarchy of rhythm actualization levels and a traditional terminology of their denotation.

Let us address one more rather important fact. It consists in the following: the natural variety of objectives and tasks of linguistic studies of rhythm, connected with specific approaches, viewpoints and aspects of its research, gives rise to a considerable number of its definitions, that traditionally appear in a great number of works (Lingvisticheskij 1990: 416, Boudreault 1968: 28, Carr 2008: 150, Roach 2009: 107, Trask 1996: 311 and others), or specific definitions, suggested in some other works (Gumovskaja 2000: 26, Martin 1924: 170, Zhirmunskij 1975: 439, Crystal 1969: 161-165, etc.).

However, in this case for the purpose of concepts unification it seems reasonable to adhere to the most general view on rhythm which we understand as the energetic foundation or communicative potential unfolding in time and providing a concentration of the utterance or text subliminal influence on the emotional and rational bases of the recipient's psychic sphere by means of alternating its manifestations that vary in the nature of their origin, regarded in linguistics as the result of a complex interaction of the language means that belong to different levels.

\subsection{Modeling the mechanism of the rhythm subliminal effect of the spoken text}

Proceeding from such a definition of rhythm we obtain the possibility to form a conventional graphical model presenting the mechanism of the rhythm subliminal potential integration in the spoken text (Fig. 1).

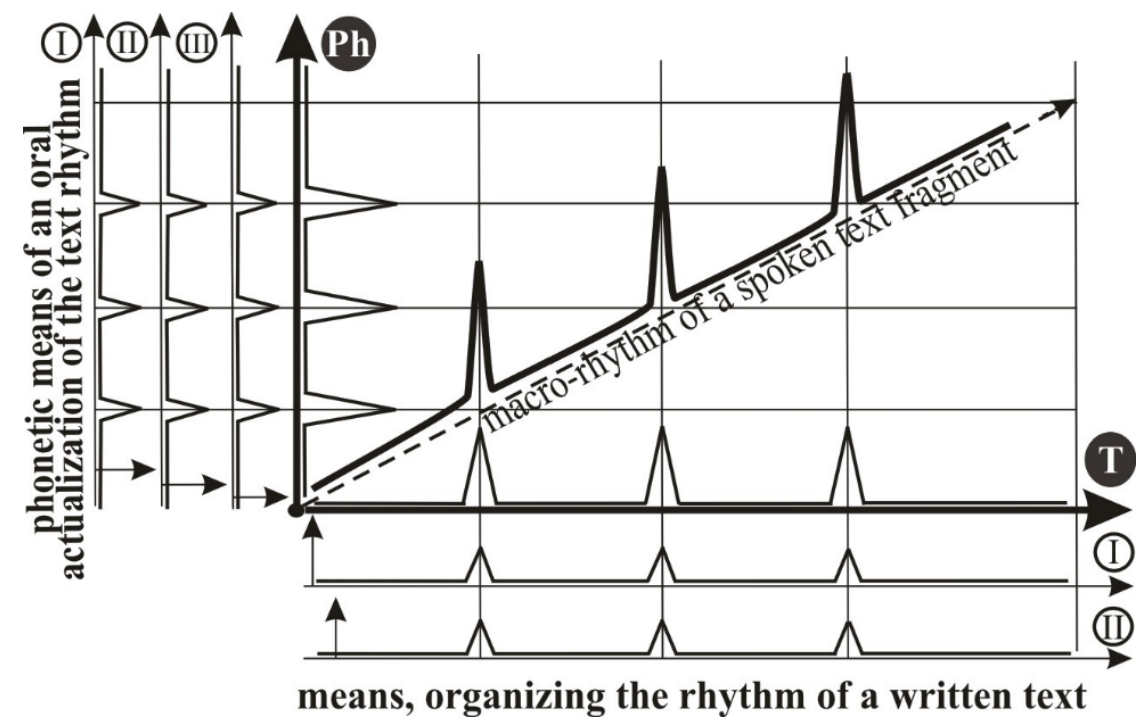

Figure 1: Model, representing the mechanism of subliminal potential integration of the spoken text's rhythm Symbol explanation: T - syntactic level of the text; I - lexical and grammatical means; II - stylistic means; Ph-phonetic level of the text; I - segmental means; II - syllabic-and-accentual means; III - suprasegmental means

With the purpose of considering the logic of the model construction let us first pay attention to K.S. Stanislavskij's ideas, who clearly differentiated the notions of rhythm and tempo-rhythm of person's thinking and speaking activities into inner and outer types of 
rhythm. In his opinion, in order to bring music, singing, words and actions to an accord, one needs rather the inner, or spiritual tempo-rhythm, than the outer, or physical one. Thus, rhythm should be felt in a sound, word, action and gait, throughout the whole performance (Stanislavskij 1954: 233). Therefore, speaking of rhythm, K.S. Stanislavskij had in mind exactly this inner rhythm (ibid.: 281) and made an attempt to explain its inner intangible characteristics (ibid.: 289). Understanding the integration of actions, music, singing, speech and actor's emotions into one outer rhythm as a major force of the performance, he chose to speak predominantly of the inner rhythm of his/her emotional experience (ibid.: 281).

In any case, we can assume that what K.S. Stanislavskij meant was a natural coordination of the actor's inner biological rhythm with the psychological and subliminal rhythm of the spoken text, which, as a result of its final shaping by prosodic means, is transformed into the outer rhythm of the materialized text fragments. Thus, interpreting the mentioned idea within the framework of linguistic terms we acquire two generalizing coordinates of the speaker's inner rhythm formation: $\mathrm{T}$ - syntactic level of the text and $\mathrm{Ph}$ - phonetic level of the text rhythm, which are, in fact, the accumulators of the language means subordinated to them. As for the syntactic level of the text, these are lexical, grammatical and stylistic means. In its turn, the phonetic level of the text rhythm accumulates segmental, syllabic-andaccentual and prosodic means.

In the process of language means' active interaction at the syntactic $(\mathrm{T})$ and phonetic $(\mathrm{Ph})$ levels of speaking and thinking activities there emerge rhythmical structures which are a consequence of the resonance/dissonance of the psycho-physiological energy of these means' generation, the result of which K.S. Stanislavskij could well identify as the inner rhythm of the text. Then with a considerable degree of certainty we can assume that the integration of inner rhythms into one single rhythm of the text materialization in speech, occurring as a result of the same resonance mechanism, was perceived by K.S. Stanislavskij and, accordingly, it must be perceived by the listener as the outer rhythm.

We believe that the logical elaboration of the conceptual views, laid into the model, represented in Fig.1, should be the basis of the process of modeling of a qualitative picture of the integration of the spoken text's rhythm subliminal potential as a consequence of its syntactic and phonetic means' interaction. The results of such modeling are presented in Fig. 2.

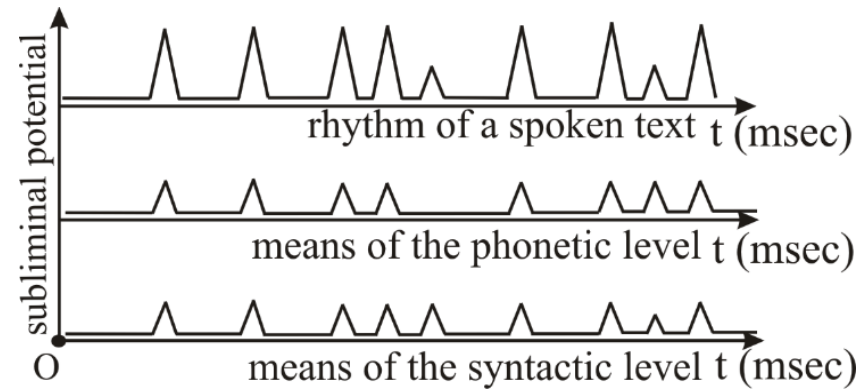

Figure 2: Graphical interpretation of the formation of the spoken text rhythm's subliminal effect

In this context let us remind that the intensity of the text's subliminal potential is essentially conditioned by rhythm as a dynamic factor of the text formation. Herewith a 
specific level of the spoken text's subliminal influence is determined, in the first place, by its rhythmic organization (German and Pishhal'nikova 1999, Rozhnov, Rozhnova 1987), reflecting the result of the addressor's speaking and thinking activities that transmit the energy of speech subliminal influence into the addressee's psychic sphere in the form of an open self-developing system.

The intensity level variability of the text rhythm subliminal potential occurs, as it has been mentioned above, as a result of resonance/dissonance of psycho-physiological energies of the inner rhythms actualized with the help of different language means used by the speaker. The emergence of resonances, achieved by way of doubling the components of the message, facilitates the appearance of additional semantics and thus it manipulates the recipient's attention (Jazykoznanie 1998: 414-415, Kiklevich 1998).

Dissonance, on the other hand, is based on the effect of rhythm interruption, which leads to the disruption of trance states, created by the continuously repeating stimuli (Kotljachkov 2001: 18) and creating a kind of arrhythmic text, capable of evoking controversial sensations in the recipient's mind (Bojchuk 2014: 131, Arustamova 1998: 17). Figuratively speaking (see Fig. 2), the dynamics of the outer rhythm arises in the moments of its transition from order to irregularity and vice versa (Sementsov 1972: 15).

Proceeding from this, on the upper axis of Fig. 2 we have reflected a qualitative pattern of the way the outer dynamic rhythm of the spoken text unfolds in time, including a specific alternation of its resonance and dissonance results. Hereby the relative peaks of the inner rhythms' energies of the text syntactic and phonetic levels, accumulated in the outer rhythm, demonstrate the values of subliminal potentials influencing the listener in the process of perceiving separate fragments of the spoken text's rhythm actualization.

\subsection{A cognitive model of the stages of tempo-rhythm generation and decoding}

As we see, from whatever viewpoint the rhythm as an object of cognition is considered, there inevitably arises a scientific problem of comparing the rhythm of two and more communicants which is traditionally resolved in linguistics by means of normalizing its main parameters. As if anticipating this, K.S. Stanislavskij (Stanislavskij 1954: 289) paid a special attention to the tempo-rhythm as a unique phenomenon, characterizing the dynamics of the individual's materialization of the spoken text. It goes without saying that similarly to the tempo, K.S. Stanislavskij differentiated the inner and outer tempo-rhythms of the person's speaking and thinking activities. The essence of such a division (Temporitm) consisted in the inner temporhythm being understood as the individual's psychic state characterized by the speed of thinking processes and emotionality. The inner tempo-rhythm materializes in the manner of speech, vigor of body gestures and the speed of the speaker's relocation in space.

Due to this, a tradition has been formed in the descriptions of tempo-rhythm to attribute the inner tempo-rhythm directly to the processes of the individual's thinking, and to assign the outer one to his/her verbal actions (Osnovy). K.S. Stanislavskij also emphasized that a proper physical behavior of an actor in the role depends on the correct tempo-rhythm of his/her inner life, as the inner tempo-rhythm influences the tempo-rhythm of his/her 
behavior. At the same time, the outer tempo-rhythm defines, in its turn, the inner emotional state of an actor, exciting in him/her the adequate emotions.

The problem of auto-subliminal function of rhythm presented in such a light is in itself interesting and important, in our opinion, for teaching expressive speaking, though it has not been thoroughly studied yet by linguists, psychologists and educationalists.

This issue is closely connected with another equally interesting and thought-provoking problem, which stimulates us to discuss cognitive models of the processes of the text temporhythm generation and decoding in oral communication. In order to present these cognitive models let us make use of the idea according to which in the psychic spheres of the addressor and the addressee there occur the following transformations: in the first case the inner temporhythm transforms into the outer one, in the second case a reverse process is observed. On the basis of this idea the cognitive model of rhythm transformation processes that take place in the addressor's psychic sphere, is given in Fig. 3.
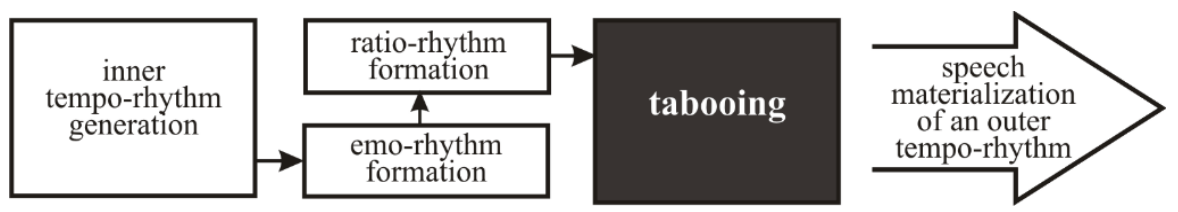

Figure 3: A cognitive model of the stages of tempo-rhythm generation in the addressor's psychic sphere

The model demonstrates that the first stage of the process of tempo-rhythm production in the addressor's psychic sphere is the generation of the inner tempo-rhythm which is unambiguously conditioned, as it has been described above, by the communicant's inner psychological and emotional states. Consequently, the initial tempo-rhythm scheme, which arises in such a way and is not apprehended by the individual, forms a particular structure of the emotional rhythm (or emo-rhythm) in the existential sphere (Kalyta 2015: 331-332) of his/her spiritual being. On account of the dialectic interaction of the emotional and rational bases of the speaker's psychic beginning, at the third stage of tempo-rhythm generation there occurs a corresponding correction of the emo-rhythm structure in his/her subconscious sphere, which results in the formation of the rational rhythm structure (or ratio-rhythm).

The essence of the fourth stage of tempo-rhythm generation, which we nominated as tabooing stage, consists in the fact that, in accordance with the norms of speech rhythm organization, formed in the process of the speaker's cultural development as well as prohibitions inherent to his/her psychic sphere, the speaker's consciousness, while defining the logic of the ratio-rhythm structure, selects an adequate tempo of its actualization thus ensuring its speech materialization in the form of the outer tempo-rhythm.

Similarly, but in a reverse order (see Fig. 4) the process of the addressee's tempo-rhythm decoding is performed. The model in Fig. 4 demonstrates that under the influence of the outer tempo-rhythm of speech flow, the emergence of the perceived text's emo-rhythm takes place in the addressee's psychic sphere. The inner emo-rhythm structure is formed on the basis of the emo-rhythm concepts' prototypes embedded in the recipient's emotional memory (Klimenjuk 2010: 221). At the second stage of the decoding process there in a similar way appears the analogue of the ratio-rhythm structure. Emo- and ratio-rhythms thus transformed and being integrated into tempo-rhythm, at the third stage undergo the tabooing 
enforcement by the recipient's consciousness. As a result of the fourth stage of text decoding by the addressee, his/her consciousness, excluding the tabooed elements, forms the structure of the inner tempo-rhythm decoded by him/her using the concepts-prototypes available as a building material in the individual's memory.

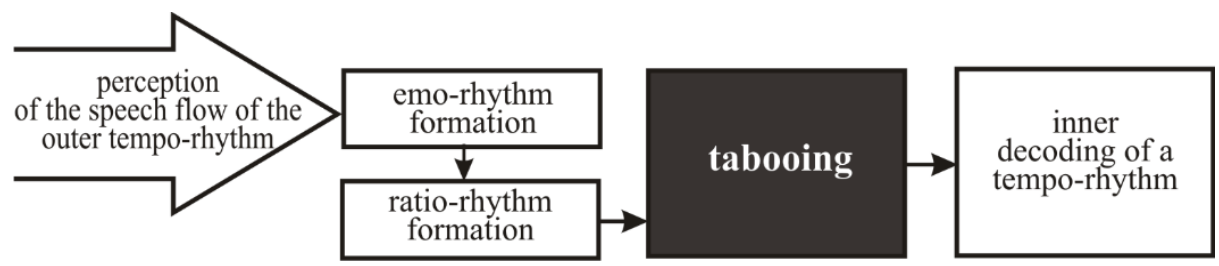

Figure 4: A cognitive model representing the stages of the process of the text tempo-rhythm decoding by the addressee

We shall observe here that in both cases the process of tabooing is performed by a specific neural structure of the communicants' brains, the functioning of which is an integral element of the work of his consciousness. N.P. Behtereva termed this structure as an error detector (Behtereva 2007: 120).

It is also known that the processes of transforming the inner tempo-rhythm into the outer one, inherently depending upon the peculiarities of the communicant's psychic sphere and his/her emotional state (Stanislavskij 1954), can in a number of cases lead to an unexpectedly acute difference of their types. This effect of tempo-rhythm generation in speech is reflected in the model, represented in Fig. 5.

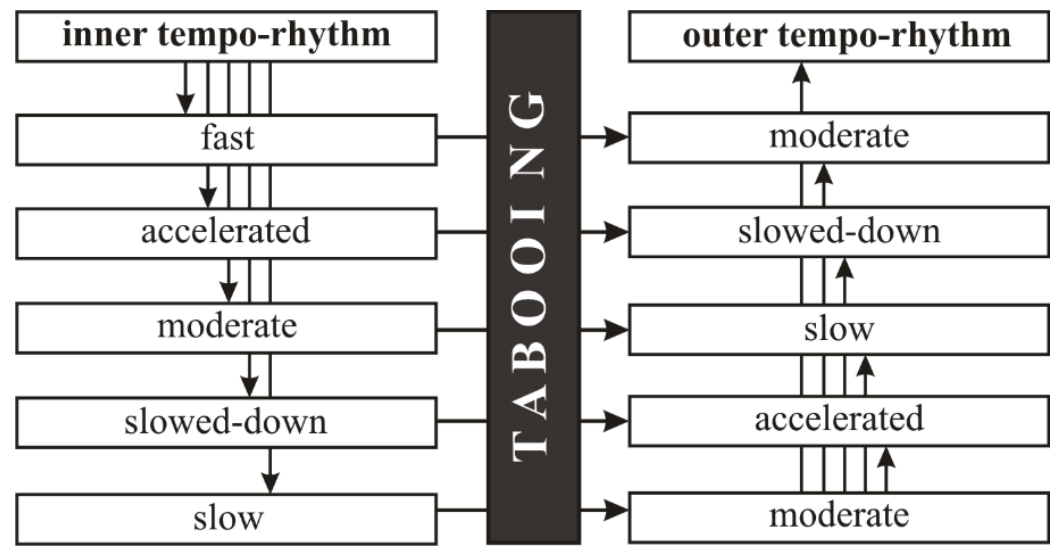

Figure 5: The model of tabooing and transformation of the inner tempo-rhythm into the outer one

Thus, for instance, the addressee's inner tempo-rhythm, accelerated by the offence, is transformed by his/her consciousness into a decelerated type of the outer tempo-rhythm as a result of tabooing which appeals to the interlocutor's higher social status and norms of communication as well as the necessity to constrain his/her emotions.

It is quite obvious that other variants of transformations indicated in the model are realized in real communication as a result of resolving by the consciousness of contradictions arising between the speech behavior norms acquired by the speaker, extra-linguistic conditions and the topic of communication, on the one hand, and the inner tempo-rhythm, generated by the speaker's psychic sphere, on the other hand. Let us pay a special attention to the varieties of tempo-rhythm types, used in the model, which we have borrowed from our 
phonetic practice (Kalyta 2001: 97-98). There are two reasons that motivate us to do this. The first one consists in the fact that the gradations of tempo-rhythm types traditional for the scientific works of psychologists and theatre experts (e.g. ultimate passivity, inertness, inactive depression, spiritual downfall, almost dying state; a gradual transition to an energetic, cheerful mood; readiness to any action, a clear purpose in the energetic, fruitful action; tempo-rhythm of the alerted attention, when a person has to make an immediate and definite decision; the rhythm of decision-making; abrupt and precise rhythm of life-assertion; overcoming serious obstacles in the energetic action; the first feeling of danger; alarm or a violent joy; a hectic pulse of life; a moment before falling into an abyss, before the shooting by a firing squad; the beginning of madness; loss of ability to apprehend and regulate one's actions, etc. (Gradacii)) are practically inapplicable in phonetic research because when viewed as the elements of the morphological classification, the mentioned types lack a common classifying feature, having instead as its criteria the inner states of the individual, his/her readiness/unreadiness to act, feelings, etc.

The essence of the second reason (and this is particularly important) consists in the fact that the unified gradation of the inner and outer tempo-rhythms according to the zones of their actualization, which we employed in the model (Fig. 5), makes it possible not only to assess the results of the inner tempo-rhythm transformation into the outer one in terms of quantity, but also to compare the dynamics of the occurring changes on the basis of normalizing the figures obtained within these zones. The application of such an approach will facilitate the experimental identification of the regularities of the mentioned tempo-rhythms' dynamics by means of calculating the factors of their acceleration and deceleration.

A further development of the methodology aimed at the quantitative assessments of the manifestations of tempo-rhythm's or spoken text rhythm's subliminal potential on the basis of the idea represented the model in Fig. 2, will make it possible to launch a practical construction of rhythm cards, or maps, and corresponding tempo-rhythm cards of any speech fragment. It should be noted here that an essential moment, that permits to construct the tempo-rhythm cards of a spoken text, is that we obtain a possibility to perform a synarchic modeling of text fragments with a similar or varying structures of tempo-rhythm actualization, the results of which can be easily assessed with the help of the appropriate factors causing the tempo-rhythm compression.

Considered thereby complex methodological problems of studying the rhythmic structure of the text allowed us to define a more complete and comprehensive content of the "tempo-rhythm" concept as a unique speech phenomenon.

According to this, text tempo-rhythm, being the dominant means of speech subliminal effect, is formed through the integration of micro-rhythms of all levels of the individual's inner speech into an inner macro-rhythm which, being adjusted by his/her emotional thinking that occurs in the existential sphere (or unconscious sphere), is structured in the form of an internal tempo-rhythm and then under the influence of a dialectical interaction of the speaker's rational (that considers specific communicative conditions) and emotional beginnings, is converted in his/her mental and transcendental spheres (or subconscious sphere) into the corresponding rational-and emo-rhythms, which are transformed as a result of consciousness' processing of the 
actual conditions and norms of communication into the outer tempo-rhythm of an utterance materialized in speech.

Hence, naturally, a question ensues regarding the hierarchy of the terminological system elements, which includes the notions of micro-rhythm, macro-rhythm, inner and outer tempo-rhythms. While considering this question we shall primarily remark that the authors of a number of linguistic works refer the notions of micro- and macro-rhythms to different levels of the text structure, as well as the language means used in it. Thus, M.M. Girshman in his work singles out a speech "micro-rhythm" and a compositional "macro-rhythm" (Girshman 1982: 78), emphasizing that the rhythm functions at all levels of literary fragments that describe actions or fragments rich in imagery, or in repetitions and contrasts of certain themes, motives, images and situations, in the regularities of plot movements, the interrelations of different compositional speech units, and in the unfolding of the system of images and characters, etc. (ibid.: 76). In her turn, E.S. Sergejeva considers the integrative role of micro- and macro-rhythm which ensures the form-making function of rhythm (Sergejeva 2007). A number of authors (see Boltaeva 2003: 14) believe that a compositional level of text structure is represented by macro-rhythm, while micro-rhythm studied by phoneticians creates the melody of the author's narration. In other works (Arustamova 1998: 17) microrhythm is explicitly referred to the author's or speaker's psychological spheres and it is believed that macro-rhythm is directly materialized in communication. There also exist approaches (Programmirovanie muzykoj), according to which micro-rhythm is attributed to the alternation of separate sounds, and macro-rhythm is ascribed to utterances or text fragments.

In pursuance of a well-known principle of relativity of any conceptual classifications we recognize the authors' objective right to refer micro- and macro-rhythms to the whole plots, structures, structural elements of all text levels, down to the separate sounds. Moreover, using the mentioned principle in the conceptual system under our consideration, we believe that it is rational to term the alternation of any speech manifestations, which vary in the nature of origin and means of their actualization, that arise in the process of formation of both inner and outer rhythms, directly integrated into inner and outer tempo-rhythms.

According to this logic in Fig. 1 (see the $\mathrm{X}$-axis) we observe a macro-rhythm of the syntactical level of the text, integrating within itself the micro-rhythms of lexical-andgrammatical as well as stylistic language means' actualization. In its turn, the macro-rhythm of the utterance phonetic level, represented on Y-axis, is formed on the basis of segmental, accentual-and-syllabic and supra-segmental micro-rhythms' integration. In compliance with the same principle of relativity, in the system of a higher level, marked by the coordinates in Fig. 1, the rhythm of a spoken text fragment will acquire a macro-rhythm status, while the rhythms of syntactic and phonetic levels of the text that generate it, can be termed as microrhythms. The very logic outlined herewith has been used for the formulation of the extended definition of speech tempo-rhythm, given above. 


\section{Conclusions}

The undertaken analysis of the specificities of text rhythmic system functioning, viewed as a psycho-physiological energetic substance, provides us with additional evidence that the generated tempo-rhythm accumulates in itself the direct connection and the character of interaction between the spiritual and material bases of individual's personality, reflecting it in oral speech.

The use of the substantiated in the paper approach will permit, firstly, to make quantitative evaluation of the effects of energetic resonance of micro- and macro-rhythms due to which the text rhythmic system ensures the achievement of a maximum subliminal potential of any of its fragments. Secondly, its application will enable one to experimentally determine the degree of changes of the text rhythmic structure subliminal potential. Thirdly, alongside with syllabic, syntagmatic, intonation and other text characteristics, this approach will expand the description of a macro-rhythm and its micro-rhythms on the basis of defining energetic and subliminal indicators of rhythm actualization in a spoken text.

We consider it quite probable that in the long run the researchers of the subliminal nature of text rhythms and mechanisms of their actualization, empowered by a corresponding interdisciplinary knowledge, will recognize the necessity of modeling a subliminal space of communicative tempo-rhythm (irrespective of whether it is termed as a cosmo-rhythm, mega-rhythm, super-rhythm, global rhythm, etc.) as a kind of a tempo-rhythm sphere, within the scope of which a pulsating interaction of energetic potentials of verbal, visual, tactile, olfactory, taste and similar concepts takes place.

\section{References}

Arustamova, A.A. 1998. Ritm prozy I.S. Turgeneva [Rhythm of I. Turgenyev's prose]. PhD diss., A.M. Gorkij Perm' state university. (in Russian)

Babicheva, A.B. 2003. Osobennosti ritmicheskoj organizacii spontannoj nemeckoj dialogicheskoj rechi na suprasegmentnom urovne (jeksperimental'no-foneticheskoe issledovanie) [Specificity of the rhythmic organization of spontaneous dialogic speech in German (experimental phonetic study)]. PhD diss., Moscow state linguistic university. (in Russian)

Behtereva, N. 2007. Magija mozga i labirinty zhizni exmepeвa [Magic of the Mind and Life Labyrinths]. Moscow: AST Publ., St-Petersburg: Sova Publ. (in Russian)

Bogatova, J.A. 2009. Simvol i ego rol'v ritmicheskoj organizacii hudozhestvennogo teksta [Symbol and its role in the rhythmic structure of a literary text]. Al'manah sovremennoj nauki i obrazovanija [Almanac of presentday science and education] 2(21), 2: 19-20. (in Russian)

Bojchuk, E.I. 2014. Ritm hudozhestvennogo teksta kak sredstvo sugestivnogo vozdejstvija [Literary text rhythm as a means of a subliminal influence]. Jaroslavskij pedagogicheskij vestnik [Yaroslav pedagogical messenger] 2, I:129-133. (in Russian)

Boltaeva, S.V. 2003. Ritmicheskaja organizacija suggestivnogo teksta [Rhythmic structure of a subliminal text]. PhD diss., A.M. Gorkij Ural state university. (in Russian)

Boudreault, M. 1968. Rythme et mélodie de la phrase parléeen France etau Québec. Paris: Librairie C. Klincksieck. Carr, Ph. 2008. A Glossary of Phonology. Edinburgh: Edinburgh University Press.

Goux, J.-P. 2003. "De l'allure" Semen. Rythme de la prose, 16. Accessed August $28,2015$. http://semen.revues.org/2664.

Crystal, D. 1976. Prosodic Systems and Intonation in English. Cambridge: Cambridge University Press. 
Efremov, V.A. 2012. Associativnye aspekty ritma liricheskoj prozy (na materiale cikla I.A. Bunina «Temnye allei») [Associative aspects of the literary prose rhythm (on the material of I. Bunin's "Dark alleys")]. Nauchnyj dialog [Scientific dialogue] 8: 88-105. (in Russian)

Gachechiladze, G.R. 1970. Vvedenie v teoriju hudozhestvennogo perevoda [Introduction to the theory of literary translation]. Tbilisi: Tbilisi National University Publ. (in Russian)

German, I.A., and V.A. Pishhal'nikova. 1999. Vvedenie v lingvosinergetiku [Introduction to Lingual synergetics]. Barnaul: Altay State University Publ. (in Russian)

Girshman, M.M. 1982. Ritm hudozhestvennoj prozy [Rhythm of literary prose]. Moscow: Soviet writer Publ. (in Russian)

Gradacii temporitmov [Tempo-rhythm Gradations]. Accessed August 22, 2015. http://psylib.org.ua/books/gippi01/txt10.htm. (in Russian)

Gumovskaja, G.N. 2000. Ritm kak faktor vyrazitel'nosti hudozhestvennogo teksta. [Rhythm as a factor of the literary text expressiveness]. Dr. of philology diss., Moscow state university. (in Russian)

Jazykoznanie. 1998. Bol'shoj jenciklopedicheskij slovar' [Language. Encyclopedia], edited by V.N. Yartseva. Moscow: Russian Encyclopedia Publ. (in Russian)

Kalyta, A.A. 2001. Fonetychni zasoby aktualizacii' smyslu anglijs'kogo emocijnogo vyslovlennja [Phonetic means actualizing the sense in English emotional utterances]. Kyiv: Kyiv State Linguistic University Publ. (in Ukrainian)

Kalyta, A.A., and L.I. Taranenko. 2012. Sistema celej i sredstv suggestivnogo vozdejstvija v kommunikacii [The system of aims and means of a subliminal influence in communication]. Visnyk Kyi'vs'kogo nacional'nogo lingvistychnogo universytetu. Serija filologija [Kyiv National Linguistic University Messenger] 15(2): 47-56. (in Russian)

Kalyta, A. 2015. Phonetic Studies from the Perspective of an Energetics Approach. In A. Bondaruk, and A. Prażmowska (eds.), Within Language, Beyond Theories (Volume I): Studies in Theoretical Linguistics, 322336. Newcastle Upon Tyne: Cambridge Scholar Publishing.

Kiklevich, A.K., and B.A. Potehina. 1998. O suggestivnoj funkcii teksta [On the subliminal text function]. Faticheskoe pole jazyka (pamjati professora L.N. Murzina) [Language phatic field (in memory of prof. L.N. Mursin)] 114-127. (in Russian)

Klimenjuk, A.V. 2007. Vyklad ta oformlennja rezul'tativ naukovogo doslidzhennja [Presentation and organization of the results of a scientific research]. Nizhin: TOV “Aspect-Polygraph” Publ. (in Ukrainian)

Klimenjuk, A.V. 2010. Znanie, poznanie, kognicija [Knowledge, learning, cognition]. Ternopil': Pidruchnyky i posibnyky Publ. (in Russian)

Kochergan, M.P. 1999. Zagal'ne movoznavstvo [General linguistics]. Kyiv: Academy Publ. (in Ukrainian)

Kotljachkov, A., and S. Gorin. 2001. Oruzhye - slovo. Oborona y napadenye s pomoshh'ju...: Praktycheskoe rukovodstvo [Word as the weapon. Defense and attack with the help of...: Practical guidelines]. Moscow: "KPS+" Publ. (in Russian)

Lingvisticheskij jenciklopedicheskij slovar'. 1990. [Linguistic encyclopedia], edited by V.N. Yartseva. Moscow: Soviet Encyclopedia Publ. (in Russian)

Martin, E.-L. 1924. Les symétries du français littéraire. Paris: Didier.

Meschonnic, H. 1990. Critique du rythme. Anthropologic historique du langage. Lagrasse: Editions Verdier.

Mourot, J. 1960. Le génie d'un style. Chateaubriand. Rythme et sonoritédans «les Mémoiresd'outre-tombe». Paris: Librairie Armand Colin.

Osnovy scenicheskogo dvizhenija. Tempo-ritm fizicheskogo dejstvija [Basics of the scene movements. Temporhythm of a physical action]. Accessed August 25, 2015. http://dramateshka.ru/index.php/bases-of-thescenic-motion/3963-osnovih-scenicheskogo-dvizheniya-05tempo-ritm-fizicheskogo-deyjstviya. (in Russian)

Programmirovanie muzykoj [Programming by music]. Accessed August 25, 2015. http://www.braincoder.ru/category/\%D0\%B7\%D0\%BE\%D0\%BC\%D0\%B1\%D0\%BE\%D1\%8F\%D1\%89\%D0 $\%$ B8\%D0\%BA/. (in Russian)

Roach, P. 2009. English Phonetics and Phonology. A practical course. Cambridge: Cambridge University Press.

Rozhnov, V.E., and M.A. Rozhnova. 1987. Gipnoz ot drevnosti do nashih dnej [Hypnosis from ancient times to present days]. Moscow: Soviet Russia. (in Russian) 
Sementsov, V.S. 1972. Ritmicheskaja struktura pojeticheskogo teksta na primere analiza Bhagavadgity [Rhythmical structure of a poetic text based on the analysis of Bhagavad-Gita]. PhD diss, Institute of oriental studies of Russian Academy of Science, Moscow. (in Russian)

Sergeeva, E.S. 2007. Ritm prozy N.V. Gogolja [The rhythm of N. Gogol's prose]. PhD diss., Moscow state linguistic university. (in Russian)

Stanislavskij, K.S. 1954. Sobranie sochinenij v vos'mi tomah: T. 1: Moja zhizn'v iskusstve [Collection of works in eight volumes. Vol. 1: My life in art]. Moscow: Iskusstvo Publ. (in Russian)

Taylor, D.S. 1981. Non-native speakers and the rhythm of English. International Review of Applied Linguistics 19: 219-226.

Temporitm [Tempo-rhythm]. Accessed August 25, 2015. http://www.psychologos.ru/articles/view/temporitm. (in Russian)

Trask, R.L. 1996. A Dictionary of Phonetics and Phonology. New York: Routledge.

Zhirmunskij, V.M. 1975. Teorija stiha [Verse theory]. Leningrad: Soviet writer Publ. (in Russian) 